\title{
Methods for The Detection of Carbapenemase in Clinical Microbiology
}

\section{Leonor Aties López ${ }^{*}$ | Miracles of Charity Milá Pascual ${ }^{2}$ | Gilberto Moya Jústiz ${ }^{3}$}

*Correspondence: Leonor Aties López

Address: ${ }^{1}$ Degree in Health Technology in Clinical Microbiology. Master in Diagnostic Media. University of Medical Sciences Faculty of Nursing-Technology. Assistant teacher. Added Investigator. Santiago de Cuba, Cuba; ${ }^{2}$ Lic. in Health Technology in Clinical Laboratory. Master in Infectious Diseases. Hospital “Dr. Ambrosio Grillo. Assistant teacher. University of Medical Sciences Faculty of Nursing-Technology. Santiago de Cuba, Cuba; ${ }^{3}$ Medical Specialist of 2nd degree in Clinical Microbiology. Provincial Teaching Hospital “Dr. Saturnino Lora Torres”. Master in Infectious Diseases. Santiago de Cuba, Cuba

e-mail $\bowtie$ : leonoraties@infomed.sld.cu

Received: 30 September 2020; Accepted: 05 October 2020

Copyright: (C) 2020 López LA. This is an open-access article distributed under the terms of the Creative Commons Attribution License, which permits unrestricted use, distribution, and reproduction in any medium, provided that the original work is properly cited.

\section{ABSTRACT}

Preliminary results obtained after applying two methods for the detection of carbapenemase, the colorimetric Bluecarba and the inactivating carbapenem, are presented, which were tested in six strains isolated from clinical samples, where satisfactory results were obtained after using both procedures. Taking into account the importance of these enzymes in Microbiology laboratories, due to the clinical-epidemiological impact they represent and the difficulty of not having molecular methods, these procedures are proposed for their detection.

Keywords: Carbapenemases, Blue-Carba Methods and Carbapenem Inactivation, Clinical Microbiology Laboratories

\section{Introduction}

The therapeutic use of penicillin and other antibiotics from the $1940 \mathrm{~s}$ on was one of the most important achievements of that century. Since then, a large number of antimicrobials have been obtained, marketed and used; however, since at the beginning of the antibiotic era there was the false hope that diseases caused by microbes would disappear, it soon became clear that bacteria were capable of developing resistance mechanisms and thus they were already known in the 1950s Penicillinresistant Staphylococcus aureus strains (Daza Pérez, 1998).

Antimicrobial resistance is not a disease, there are usually no differences in severity between diseases caused by susceptible strains and resistant strains. Resistance is not usually a problem of pathogenesis, but rather of limitation of therapeutic options. The basic problem is that we depend on antimicrobials to treat infections. If there were alternative methods to treat them, antimicrobial resistance would persist, but it would no longer be important as a public health problem (World Health Organization). It is a growing phenomenon characterized by the natural or acquired capacity of a bacterial strain to remain refractory to the bactericidal or bacteriostatic effects of an antimicrobial. The 
indiscriminate use of antibiotics and the selective environmental pressure, carried out by antiseptics and disinfectants, has generated a survival response in microorganisms, which enables them to effectively evade the bactericidal action of antimicrobials (Slicing, 2015).

Bacterial resistance has now become a serious global health problem and requires the maximum effort of all government institutions to ensure its control. Given that this phenomenon has as its main consequences the failure of antimicrobial therapy, the increase in morbidity and mortality, and the increase in the costs of medical care, its containment at the international level is essential (Resurrección et al., 2017).

\section{Developing}

In recent years, there has been the emergence and dispersal of gram-negative bacteria capable of expressing enzymes, such as carbapenemases, which confer high resistance to betalactam antibiotics, including carbapenems. This group of enzymes is a heterogeneous mixture of beta-lactamases, which, according to the Ambler classification, may belong to class B or Zn-dependent metallobetalactamases (MLB), and to classes A and D or serinecarbapenemases. The most prevalent MBL in clinical strains are those belonging to the VIM and IMP types. Subsequently, a new type has been described, the so-called New Delhi metallo-beta-lactamase (NDM-1) that inactivates, like the previous ones, all beta-lactams except aztreonam, although most of the strains that harbor the blaNDM- gene 1 jointly produce other extended-spectrum beta-lactamases that affect the latter, making these pathogens absolutely resistant to all beta-lactams (Khalifa et al., 2017; Montúfar et al., 2016; van der Zwaluw et al., 2015).

The detection of these enzymes in clinical isolates continues to be a problem in Microbiology laboratories, the authors estimate that although molecular techniques are considered the reference methods to confirm the presence of the genes of the different carbapenemases, these techniques are not usually available in the context of our regular medical practice. For this reason, they have applied two methods for the detection of carbapenemases, the Blue-carba colorimetric method and Carbapenemase inactivation (CIM), where they have obtained the first results, with six isolates from clinical samples being positive for both tests, being located in criterion II, which are those that turn from blue to green.

Researchers consider that the Blue-carba method is easy to do and fast for the issuance of the results, since depending on the type of enzyme, yellow or green color changes can be observed between 15 minutes to 2 hours, the second procedure According to the authors of the reviewed bibliographies (Molin, 2016; March Rosselló, 2017; Mediavilla et al., 2017), it can be read in 6 or 8 hours, although they recommend reading after incubating the plates overnight. Similar results were obtained in this study after the recommended incubation time. 
Note in (Fig. 1), Blue-carba method, the positivity due to the change in color from blue to green and yellow, in (Fig. 2), carbapenem inactivation method, the growth around a $10 \mu$ g meropenem disk indicates activity of carbapenemase, while the absence of growth proves the opposite.

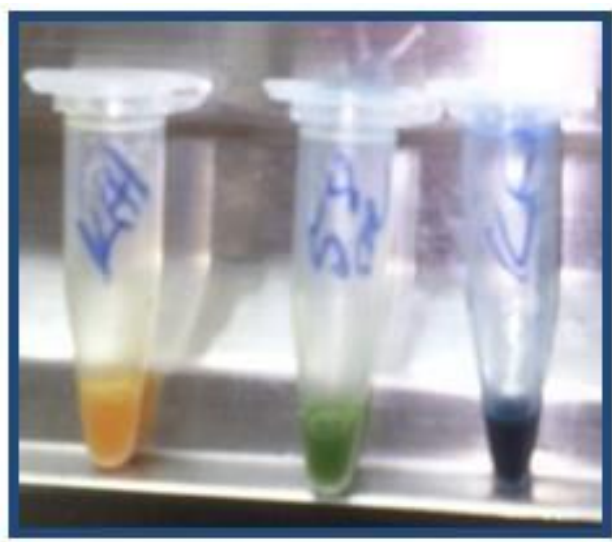

Figure 1: Blue-carba

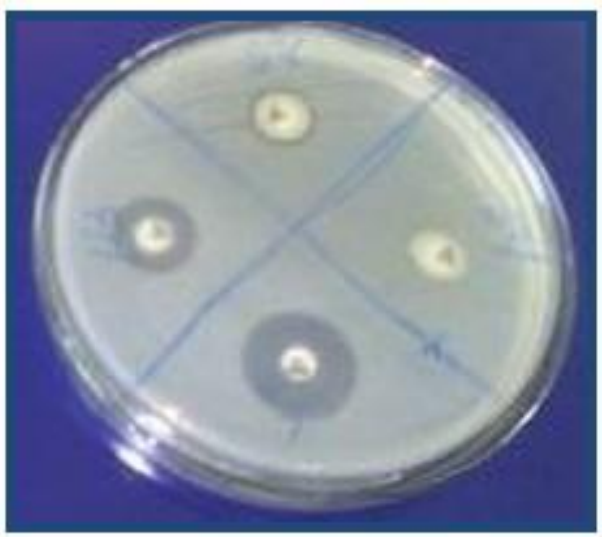

Figure 2: Carbapenemase Inactivation

\section{Conclusions}

It should be noted that both methods are feasible for the diagnosis of these carbapenemic antimicrobial inactivating enzymes, easy to perform and inexpensive, which can be implemented in clinical microbiology laboratories as long as molecular, more accurate, but highly expensive methods are not available.

\section{References}

Daza Pérez RM. Bacterial resistance to antimicrobials: its importance in decision-making in daily practice. Therapeutic Information of the National Health System 1998; 22: 3.

Khalifa HO, Soliman AM, Ahmed AM, Shimamoto T, Hara T, Ikeda M, Kuroo Y, Kayama S, Sugai M, Shimamoto T. High carbapenem resistance in clinical gram-negative pathogens isolated in Egypt. Microb Drug Resist 2017; 23: 838-844.

March Rosselló GA. Rapid methods for the detection of bacterial resistance to antibiotics. Rev Enferm Infecc Microbiol Clin 2017; 35: 182-188.

Mediavilla Gradolph C, Sáinz Rodriguez R, Valverde Troya M, de Toro Peinado, Bermudez Ruíz M P, Palop-Borrás B. Evaluation of an immunochromatographic assay for the detection of OXA-48 carbapenemase. Rev Esp Quimioter 2017; 30: 4549.

Molin C. Phenotypic Detection of Carbapenemases in Pseudomonas aeruginosa in Patients who attended the Hospital de Clínicas San Lorenzo from February to July 2013. Mem Inst Investig Science Health 2016; 14: 25-31.

Montúfar-Andrade FE, Mesa-Navas M, Aguilar-Londoño C, Saldarriaga-Acevedo C, Quiroga-Echeverr A, Builes-Montaño CE, Villa-Franco JP, Zuleta-Tobon JJ, Montúfar-Pantoja MC, Monsalve MA, Hernández C. Clinical experience with infections caused by carbapenemase-producing Klebsiella pneumoniae in a tertiary care teaching institution in Medellin, Colombia. Rev Infectio 2016; 20: 17-24. 
Resurrección-Delgado C, Montenegro-Idrogo JJ, Chiappe-Gonzalez A, Vargas-Gonzales R, Cucho-Espinoza C, MamaniCondori DH, Huaroto-Valdivia LM. Klebsiella pneumoniae New Delhi metalo-lactamase in a Peruvian national hospital. Peru Rev Peru med exp public health 2017; 1: 261-7.

Slicing E. Detection of carbapenemase-producing Enterobacteriaceae in the laboratory routine. Rev Esp Quimioter 2015; 28: 8-11.

van der Zwaluw K, de Haan A, Pluister GN, Bootsma HJ, de Neeling AJ, Schouls LM. The carbapenem inactivation method (CIM), a simple and low-cost alternative for the Carba NP test to assess phenotypic carbapenemase activity in gram-negative rods. PloS one 2015; 10: e0123690.

World Health Organization. Drug resistance. Importance of antimicrobial resistance for public health. Available at: http://www.who.int/drugresistance/AMR_Importance/es 